PACS: $87.14 . \mathrm{C}++\mathrm{c}$, 87.16.Dg

\title{
MOLECULAR DYNAMICS SIMULATION OF THE INTERACTION BETWEEN BENZANTHRONE DYE AND MODEL LIPID MEMBRANES
}

\author{
DOlga Zhytniakivska \\ Department of Medical Physics and Biomedical Nanotechnologies, V.N. Karazin Kharkiv National University \\ 4 Svobody Sq., Kharkiv, 61022, Ukraine \\ *Corresponding Author: olya zhitniakivska@yahoo.com \\ Received 15 June 2020, revised June 28, 2020; accepted June 30, 2020
}

The benzanthrone fluorescent dyes are known as environmentally-sensitive reporters for exploring the physicochemical properties and structural alterations of lipid membranes. In the present work the 100-ns molecular dynamics simulation (MD) was used to characterize the bilayer location and the nature of interactions between the benzanthrone fluorescent dye ABM and the model lipid membranes composed of the zwitterionic lipid phosphatidylcholine (PC) and its mixtures with the anionic lipid phosphatidylglycerol (PG20) and sterol cholesterol (Chol30). The MD simulations were performed in the CHARMM36m force field using the GROMACS package. The ABM molecule, which was initially placed at a distance of $30 \AA$ from the midplane of the lipid bilayer, after $10 \mathrm{~ns}$ of simulation was found to be completely incorporated into the membrane interior and remained within the lipid bilayer for the rest of the simulation time. The analysis of the MD simulation results showed that the lipid bilayer location of the benzanthrone dye ABM depends on the membrane composition, with the distance from bilayer center being gradually shifted from $0.78 \mathrm{~nm}$ in the neat PC bilayer to $0.95 \mathrm{~nm}$ and $1.5 \mathrm{~nm}$ in the PG- and Chol-containing membranes, respectively. In addition, the partitioning of the ABM into the neat PC bilayer was followed by the probe translocation from the outer membrane leaflet to the inner one. A separate series of MD simulations was aimed at examining the ABM influence on the lipid bilayer structure. It was found that ABM partitioning into the lipid bilayers of various composition has no significant effect on the orientation of the fatty acid chains and leads only to a small increase of the deuterium order parameter for the carbon atoms 5-to- 8 in the $s n-2$ acyl chains of the neat PC membranes. In addition, the interaction of the ABM with the model lipid membranes caused the slight decrease of the surface area per lipid pointing to the slight increase of the packing density of lipid molecules in the presence of ABM. The results obtained provide a basis for deeper understanding of the membrane interactions of benzanthrone dyes and may be useful for the design of the novel fluorescent probes for membrane studies. KEYWORDS: ABM, benzanthrone dye, lipid bilayer, molecular dynamics simulation.

The benzanthrone dyes, a well-known class of fluorescent probes that emit in the spectral region from yellow-green to red-purple (depending on the dye structure), have found diverse applications in biomedical research and diagnostics due to their favorable spectral characteristics, such as a large extinction coefficient, a marked Stokes shift; negligible fluorescence in an aqueous phase, etc [1-10]. Specifically, it has been shown that the benzanthrone dye in combination with the thin polylactic acid film is capable of displaying the antimicrobial activity against Gram-positive and Gramnegative bacteria [11]. Staneva et al. also demonstrated a good antimicrobial activity against the Gram-positive $B$. cereus and the yeasts $C$. lipolytica bacteria for the dendrimers modified with eight fluorescent benzanthrone chromophore units [12]. A good deal of studies indicate that benzanthrone dyes can be used as effective microenvironmental sensors for monitoring structural changes in biological systems [2-14]. In particular, the benzanthrone derivatives were employed in DNA [8], protein [4-6] and membrane studies [7,9,10,13]. Notably, Dobretsov and Vladimirov demonstrated that one representative of the benzanthrone class, 3-methoxybenzanthrone can be effectively used to monitor the membrane structural changes caused by the alterations in cholesterol (Chol) level, temperature, $\mathrm{pH}$, etc. [3]. Likewise, the high lipidassociating ability was also observed for other amino- and amidinobenzanthrones [7,13]. Moreover, the spectral responses of some benzanthrone dyes in different lipid systems have been shown to correlate with the degree of lipid bilayer hydration [9], rendering these probes highly suitable for examining the membrane-related processes, especially those coupled with the changes in membrane polarity [7]. The applicability of the novel benzanthrones is not limited to the membrane studies since these dyes are extensively used in the protein research field, for instance, in the studies of a particular class of protein aggregates, amyloid fibrils [4-7]. Specifically, it has been shown previously that aminobenzanthrones are capable of distinguishing between the native monomeric and fibrillar protein states, surpassing the classical amyloid marker ThT in the sensitivity to the lysozyme amyloid fibrils $[3,4,6]$. Moreover, it has been shown that the benzanthrone dyes are sensitive to the distinctions in fibril morphology [4] and can be effectively used to characterize amyloid fibrils in terms of their fractal-like dimensions [6].

Increasing evidence indicates that one representative of aminobenzanthrones, ABM, may be especially useful for exploring the alterations of the structural and functional properties of cells during different pathologies such as lung tuberculosis [14], gastrointestinal tract cancer [15], rheumatoid arthritis [16], chronic myeloid and B-cells lymphoid leukemia [14], as well as for the check-up of the Chernobyl clean-up workers [17]. Specifically, it was found that spectral characteristics of the benzanthrone dye ABM correlate with a number of parameters of cellular and artificial membranes such as physicochemical properties of a ipid bilayer, microviscosity, proliferating and lipid metabolic activities of cells, distribution of lymphoid subsets, etc [14-17]. Despite numerous applications of ABM in the membrane studies, the molecular details of the dye-membrane complexation, its distribution across the membrane and the depth of location in a lipid bilayer are still unknown. To fill this gap, in the present investigation the molecular dynamics technique was used (C) O. Zhytniakivska, 2020 
to gain deeper insights into the nature of ABM interactions with a lipid bilayer. More specifically, the aim of our study was twofold: i) to uncover the molecular level details of ABM partitioning in the homogenous phosphatidylcholine bilayer and the bilayers from PC mixtures with anionic lipid phosphatidylglycerol and sterol cholesterol; ii) to examine how the membrane location of the probe depends on the lipid bilayer composition.

\section{EXPERIMENTAL SECTION}

The molecular dynamics simulations and analysis of the trajectories were performed using the GROMACS software (version 5.1) with the CHARMM36m force field. The calculations were performed at a temperature of $310 \mathrm{~K}$. The input files for MD calculations were prepared using the web-based graphical interface CHARMM-GUI [18]. The .pdb-file of ABM was created in OpenBabelGUI 2.4.1, using the structure drawn in MarvinSketch (.mrv format). The partial charges of AMB were corrected using the RESP ESP charge Derive Server. The topology of the ABM was generated using the CHARMM-GUI Ligand Reader and Modeler [19]. The obtained files were further used to generate the dye-lipid systems using the Membrane Builder option [20]. The three different ABM-membrane systems were created for the simulation with a nearly identical number of lipids. One system was composed of ABM and a lipid bilayer containing 94 PC (palmitoyl-oleyl-phosphatidylcholine) molecules in each monolayer. The second and the third systems were represented by the ABM and heterogeneous lipid bilayers composed of PC and PG (paimitoyl-oleyl-phosphatidylglycerol) or cholesterol (Chol), respectively. The molar ratios PC/PG and PC/Chol were 4:1 and 7:3, respectively. In order to examine the effects of ABM on the lipid bilayer properties, the ABM-free PC, PC/PG (4:1) and PC/Chol (7:3) bilayers were also simulated. Hereafter, the systems containing $20 \mathrm{~mol} \%$ of PG and $30 \mathrm{~mol} \%$ of Chol are referred to as PG20 and Chol30, respectively. The MD simulations of ABM-lipid systems were carried out in the NPT ensemble. The ABM molecule was translated to a distance of $30 \AA$ from the membrane midplane along the bilayer normal. The TIP3P water model was used. To obtain a neutral total charge of the system a necessary number of counterions was added. For correct treatment of the long-range electrostatic interactions, the Particle Mesh Ewald algorithm was utilized [21]. The bond lengths were constrained using the LINC algorithm [22]. The pressure and temperature controls were carried out using the Berendsen thermostat [23]. The minimization and equilibration of the system were performed during 50000 and 5000000 steps, respectively. The time step for MD simulations was $2 \mathrm{fs}$. The whole time interval for MD calculations was $100 \mathrm{~ns}$. The GROMACS commands gmx density and gmx order, were used to calculate the mass density distribution for various components of the lipid bilayer, density distribution of ABM across a lipid bilayer and deuterium order parameter profiles, respectively. The analysis of the membrane thickness, membrane area and area per lipid were performed using the FATSLiM package [24]. The molecular graphics and visualization were performed using the VMD software.

\section{RESULTS AND DISCUSSION}

During the last decades the molecular dynamics simulation has become a powerful tool in characterizing the atomic-level details of the interaction between peptides [25,26], proteins [27], organic solvents [28,29] and drugs [30] with lipid membranes. Moreover, MD simulation appeared to be especially useful in studying the behavior of fluorescent membrane probes [31-34]. The increasing use of the MD techniques in the dye-membrane studies is dictated mainly by the difficulties in the determination of the probe location by the experimental methods [*]. To exemplify, the molecular dynamics simulation was used to characterize the partitioning and disposition of the diphenylhexatriene probes [32], ESIPT fluorophores [31], coumarin derivatives [33], membrane polarity probes Prodan and Laurdan [34,35], to name only a few. In the present study the 100-ns molecular dynamics simulation was used to investigate the lipid bilayer location and interactions between the fluorescent probe ABM and the model lipid membranes composed of zwitterionic lipid PC and its mixtures with anionic lipid PG and sterol Chol. Fig. 1 illustrates the disposition of the benzanthrone dye with respect to the lipid/water interface at different simulation times. From a simple visual inspection of simulation snapshots, it is apparent that ABM molecule, which was initially placed at a distance of $30 \AA$ from the bilayer midplane, after $\sim 10 \mathrm{~ns}$ of simulation was found to be fully incorporated into the membrane and remained within the lipid bilayer for the rest of simulation time. Specifically, the probe moved to the bilayer polar region and is positioned at the level of glycerol moiety of the upper leaflet of PC and PG20 membranes (the distance from bilayer center $\sim 1.5 \mathrm{~nm}$ ) and at the level of PC choline nitrogen of the Chol30 lipid bilayer (the distance from bilayer center $\sim 2.0 \mathrm{~nm}$ ). During the further time of simulation, the deeper penetration of ABM in the membrane interior was observed coupled with the slowdown of the dye movement. The right panel of the Fig. 1 demonstrates location of ABM at the $100 \mathrm{~ns}$ of simulations. The snapshots demonstrate that lipid bilayer partitioning of ABM strongly depends on the membrane composition. Accordingly, ABM is localized mainly in the hydrophobic part of the PC and PG20 lipid bilayers. In turn, in the Chol30 bilayer ABM prefers the binding sites which are closer to the membrane surface.

Fig. 2 shows the time evolution of the separation of ABM center of mass from the bilayer center for the neat PC (black line) and the mixed PG20 (blue line) and Cho30 (red line) lipid bilayers. The bilayer center is defined as the average position of the $\mathrm{C} 316$ and $\mathrm{C} 218$ carbons on the termini of PC tails. The analysis of the positions occupied by ABM molecule during the molecular dynamics simulation (Fig.2.) indicates that this probe prefers the region separated by a distance $c a .0 .8 \mathrm{~nm}$ from the PC bilayer center. Remarkably, the obtained results are in good agreement with the experimental measurements [7,10]. More specifically, based on the quantitative parameters of the dye-membrane binding derived from the fluorimetric titration data and the red-edge excitation shift of the membrane-bound dyes it 
was hypothesized previously that ABM is localized in the nonpolar bilayer region near the lipid carbonyl groups [7]. Interestingly, these findings are consistent with those obtained for other benzanthrone dyes [10]. Specifically, the study of the Förster resonance energy transfer between the anthrylvinyl-labeled phosphatidylcholine as a donor and the newly synthesized benzanthrones as acceptors showed that benzanthrone dyes tend to penetrate into the hydrophobic region of PC bilayer, with limiting separations from the membrane center falling in the range $0.5-1.3 \mathrm{~nm}$ [10]. Notably, the diphenylhexatriene membrane probes DPH and TMA-DPH which are commonly used for the measurements of membrane fluidity are located also at the non-polar membrane region (with the distance from bilayer center $\sim 0.7 \mathrm{~nm}$ and $0.9 \mathrm{~nm}$ for DPH and TMA-DPH, respectively) [32].

PC
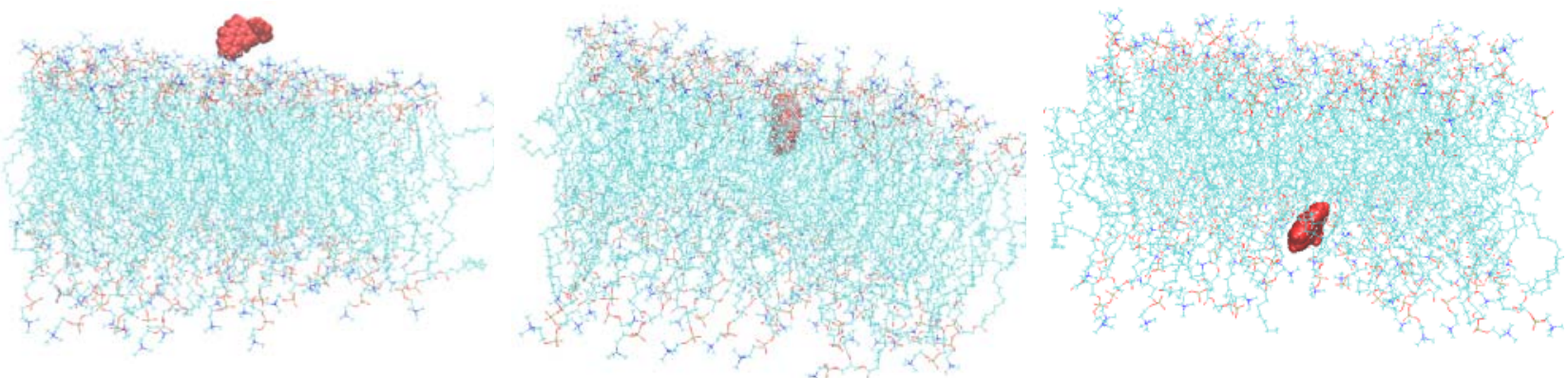

PG20
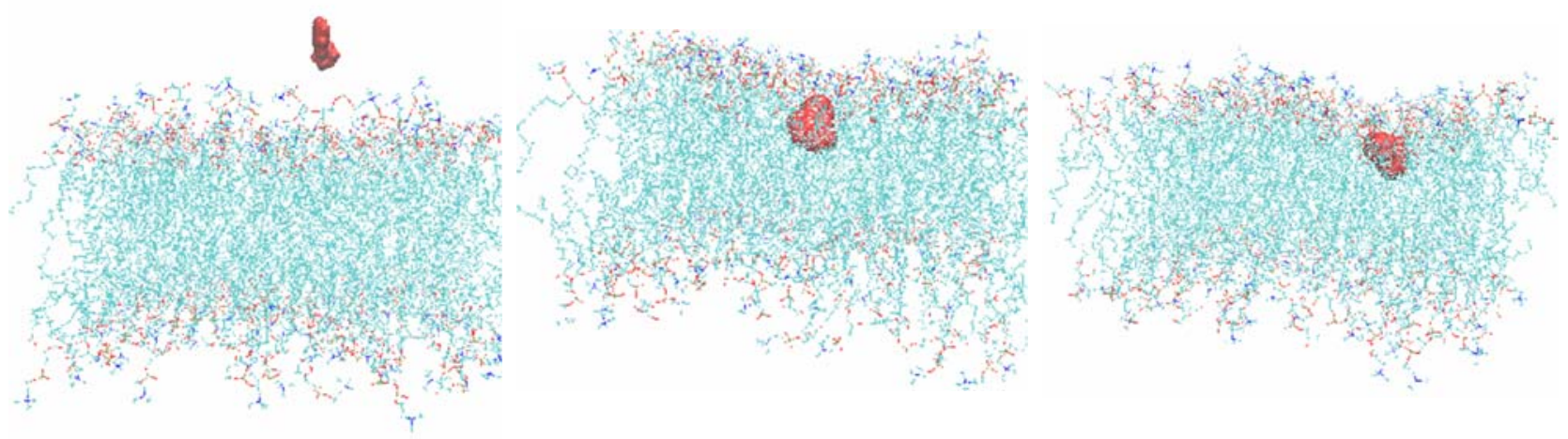

\section{Chol30}

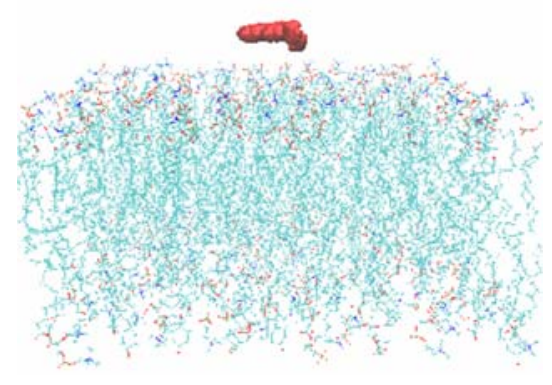

O ns

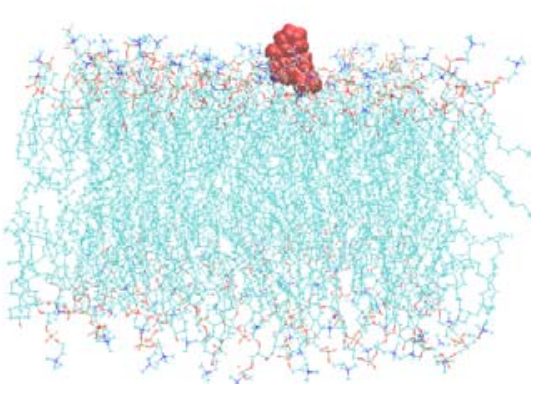

$10 \mathrm{~ns}$

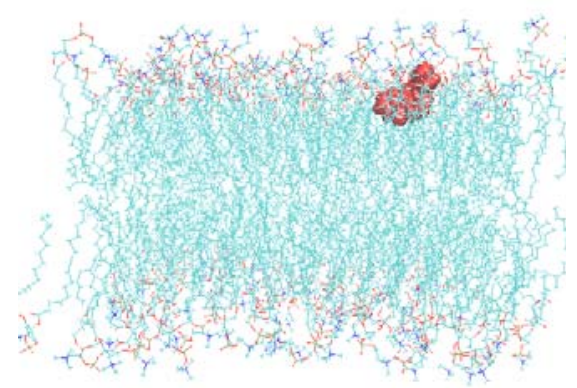

$100 \mathrm{~ns}$

Figure 1. The snapshots of the partitioning of ABM into PC, PG20 and Chol30 bilayers at different simulation time points. The $\mathrm{ABM}$ is depicted in red using the VDW drawing method. The lipid tails are represented as sticks in cyan, the phosphorus and nitrogen atoms of the lipid headgroups are shown by orange and blue, respectively. For clarity, water molecules and ions are not shown. (For the interpretation of the references to color in this figure legend, the reader is referred to the web version of this article).

It should be noted that in the PG20 and Chol30 lipid bilayers the benzanthrone dye under study tends to occupy more polar membrane binding sites since ABM center of mass was localized at the distances $\sim 0.95 \mathrm{~nm}$ and $1.5 \mathrm{~nm}$ from the membrane midplane, respectively. The obtained results are in good agreement with the recent studies indicating that inclusion of anionic lipids into PC bilayer induces a relocation of the benzanthrone dyes from the hydrophobic membrane core to the lipid-water interface [10]. Moreover, taken into account the ability of cholesterol to alter the lipid packing density of the PC bilayer [36] and a well-known Chol condensing effect [37], it seems energetically unfavorable to ABM to penetrate deeply in the Chol30 bilayer hydrophobic region and the probe tends to locate at the level of glycerol backbone. 


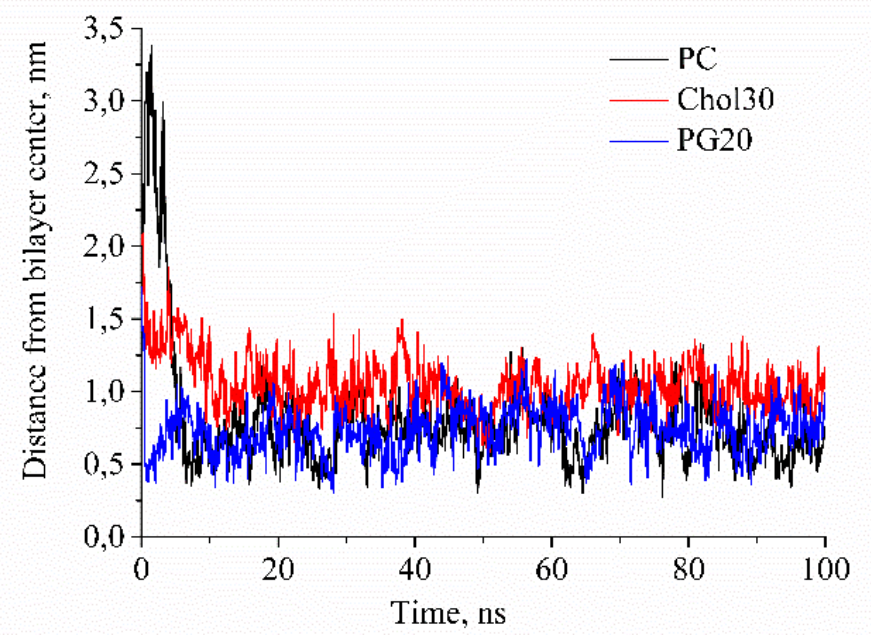

Figure 2. Time evolution of the ABM distance from the bilayer center

Another interesting observation is the translocation of the ABM molecule from the upper leaflet to the lower one of the PC bilayer (Fig. 1, right column). Therefore, at the next step of study the ABM distribution across the lipid bilayer was studied. Fig. 3 represents the mass density distribution of the ABM probe, the molecular groups of lipids (polar heads, glycerols and acyl chains) and water. The position of the selected groups was averaged with respect to the bilayer normal for all atoms over the $100 \mathrm{~ns}$ of the MD sampling trajectories. As can be seen, the peak of the ABM mass distribution in the PG20 (Fig.3 B) and Chol30 (Fig. 3C) bilayers is observed at the distances 0.95 and $1.5 \mathrm{~nm}$ from the bilayer center.
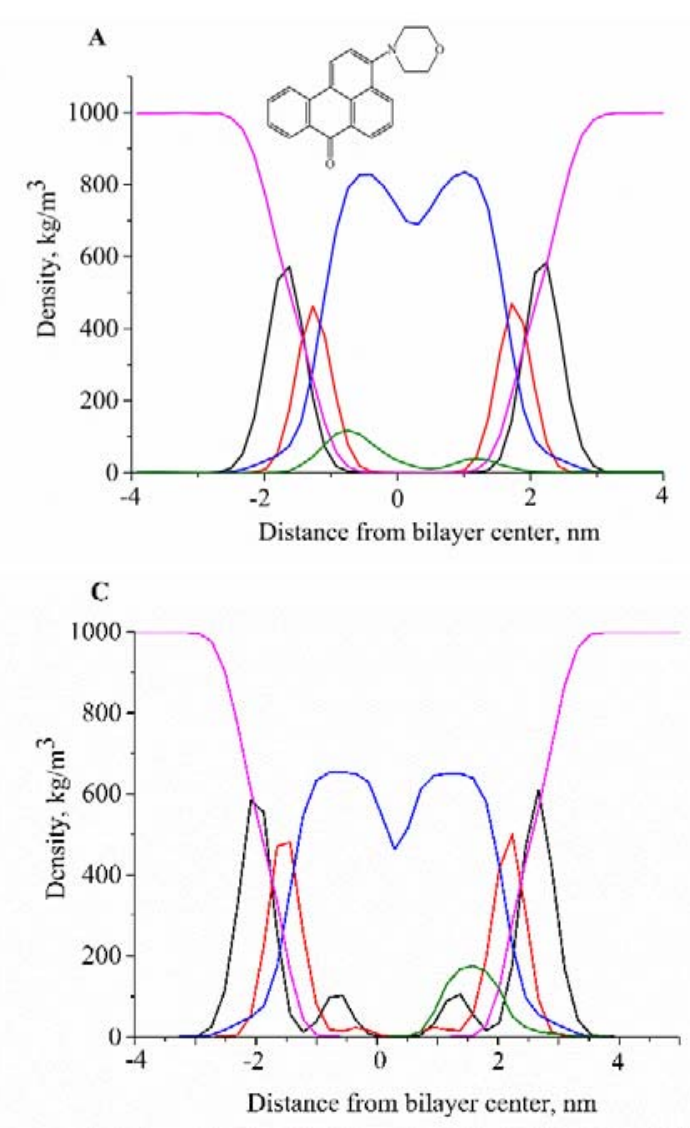

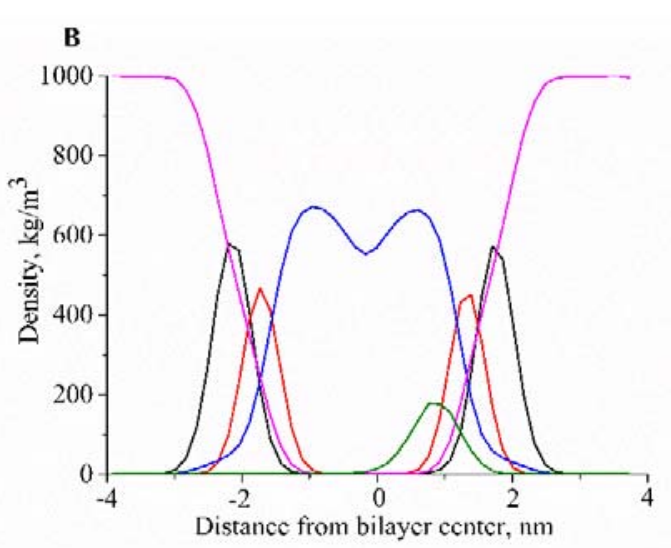

Figure 3. Mass density distribution of the ABM probe( green solid) across the PC (A), PG20 (B) and Chol30 (C) bilayer. The density distribution of water (magenta), acyl chains (blue), glycerols (red) and polar heads (black) are ploted with respect to the bilayer center. To improve the visualization, the mass density of ABM was scaled by a factor of 20. Shown in the inset of panel $\mathrm{A}$ is the ABM structure (For the interpretation of the references to color in this figure legend, the reader is referred to the web version of this article)

In turn, the ABM mass density profile in the PC bilayer is characterized by two peaks. The first low-intensive peak is placed at $1.2 \mathrm{~nm}$ from the bilayer center (the region of carbonyl groups) at the outer membrane leaflet, while the second one at $\sim 0.75 \mathrm{~nm}$ is attributed to the probe location in the acyl chain region. As seen from Fig. 1., A, the ABM is able to change its bilayer leaflet within the timescale of the simulation. It is noteworthy that the possibility of the probe translocation between the bilayer leaflets was previously observed for DPH [32,36]. Specifically, Repakova et al. observed the four leaflet changes for DPH in the fluid 1,2-dipalmitoyl-phosphatidylcholine bilayer during $400 \mathrm{~ns}$ MD simulation [36]. The translocation of DPH was described also for the palmitoyl-oleyl-phosphatidylcholine (POPC) 
bilayers and Chol-containing membranes, with the magnitude of this effect being significantly higher for a less ordered POPC bilayer [32].

Next, to ascertain the ABM influence on the lipid bilayer structure, the deuterium order parameter profiles characterizing the average orientation of the fatty acid chains with respect to the bilayer normal were calculated (Fig. 4).
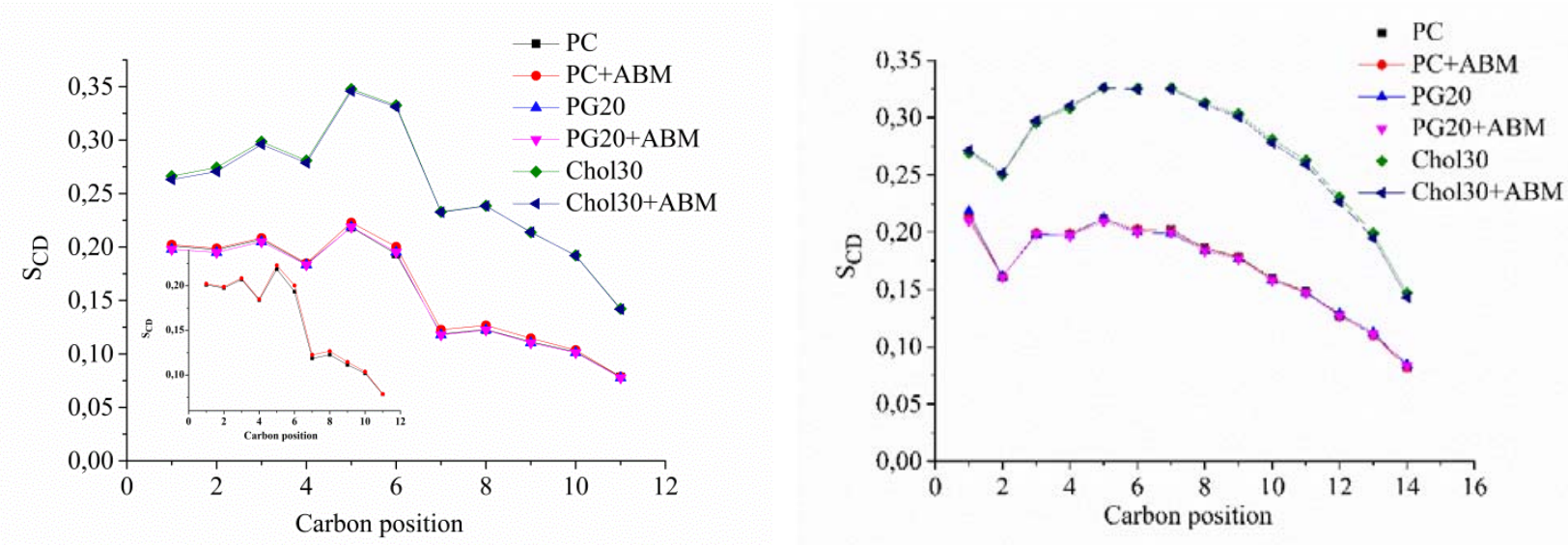

Figure 4. The calculated deuterium order parameter versus carbon position for $s n-1$ (right panel) and $s n-2$ (left panel) chain for PC, PG20 and Chol30 bilayers in the absence and presence of the ABM. Shown in the inset are lipid order parameters for the neat PC bilayer.

The chain order parameter $S_{C D}$ is defined through the order parameter tensor:

$$
S_{C D}=1 / 2\left(3\left\langle\cos ^{2} \theta_{C D}\right\rangle-1\right)
$$

where $\theta_{C D}$ is the angle between the $\mathrm{CD}$ bond and the membrane normal. As seen in Fig.4, the ABM partitioning in the PC, PG20 and Chol30 lipid bilayers does not affect the order of $s n-1$ and $s n-2$ acyl chains, except the $s n-2$ acyl chains of PC membranes (the inset in Fig.4) for which a small increase of the $S_{C D}$ value was observed for the carbon atoms 5-to8. These results correlate well with the previously reported observations that the low and moderate concentrations of the probe molecules have no essential influence on the structure of lipid bilayers $[31,35]$.

One of the macroscopic parameters describing the ordering and packing of lipid molecules is the surface area per lipid molecule. The average values of the surface area per lipid calculated in MD simulations were equal to $63.4 \pm 1.0 \AA^{2}$, $66.3 \pm 1.0 \AA^{2}, 55.2 \pm 0.9 \AA^{2}$, for the PC, PG20 and Chol30 lipid bilayers, respectively. These values are in good agreement with the results from previous simulations and experiments [37,38,39]. The ABM partitioning into the lipid membranes caused the slight decrease of this parameter to $62.9 \pm 0.9 \AA^{2}, 65.5 \pm 1.0 \AA^{2}, 54.6 \pm 0.9 \AA^{2}$, for the PC, PG20 and Chol30 lipid bilayers, respectively. The obtained results are in harmony with the previously reported findings that the binding of some fluorescent dyes and drugs could lead to the decrease in the surface area per lipid.

\section{CONCLUSIONS}

In the present study the behavior of the benzanthrone dye ABM as a membrane probe was investigated using the $100 \mathrm{~ns}$ molecular dynamics simulation of this compound in the neat phosphatidylcholine and the mixed phospatidylcholine/phosphatidylglycerol or phosphatidylcholine/cholesterol lipid bilayers. The MD simulation results showed that the ABM molecule, which was initially placed at a distance of $30 \AA$ from the bilayer midplane, after $\sim 10 \mathrm{~ns}$ of simulation became incorporated into the membrane and remained within the lipid bilayer for the rest of the simulation time. The analysis of the positions occupied by the ABM in the lipid bilayers of various composition revealed that this reporter molecule enters into the depth of the neat PC membrane preferring the region separated by a distance $c a$. $0.8 \mathrm{~nm}$ from the PC bilayer center. In turn, in the PG20 and Chol30 lipid bilayers the examined benzanthrone dye tends to occupy more polar membrane binding sites distributing at the distances $\sim 0.95 \mathrm{~nm}$ and $1.5 \mathrm{~nm}$ from the membrane midplane, respectively. It was found that $\mathrm{ABM}$ does not significantly perturb the lipid bilayer structure. Overall, the outcomes of this study may prove of importance for the structural design of the novel fluorescent probes for membrane studies.

\section{ACKNOWLEDGEMENTS}

This work was supported by the Ministry of Education and Science of Ukraine (the Young Scientist projects № 0117 U004966 "Nano- and microsized liophylic and liophylized self-associated systems: application in modern technologies and biomedicine" and the project № 0119U002525 "Development of novel ultrasonic and fluorescence techniques for medical micro- and macrodiagnostics"). The author is grateful to Dr.Sci. Galyna Gorbenko, V. N. Karazin Kharkiv National University, for useful comments and discussions.

(D) Olga Zhytniakivska, https://orcid.org/0000-0001-9554-0090 


\section{REFERENCES}

[1]. I. Grabchev, V. Bojinov, I. Moneva, Dyes Pigm. 48, 143-150 (2001), https://doi.org/10.1016/S0143-7208(00)00098-X.

[2]. E. M. Kirilova, I. Kalina, G. Kirilov, et al., Nature J. Fluoresc. 18, 645-648 (2008), https://doi.org/10.1038/78948.

[3]. G. Dobretsov, V. Dmitriev, L. Pirogova, V. Petrov, Yu Vladimirov, Stud. Biophys. 71, 189-196 (1978).

[4]. K. Vus, V. Trusova, G. Gorbenko, R. Sood, E. Kirilova, G. Kirilov, et al., J. Fluoresc. 24, 193-202 (2014), https://doi.org/10.1007/s10895-013-1318-3.

[5]. K. Vus, V. Trusova, G. Gorbenko, E. Kirilova, G. Kirilov, I. Kalnina, P. Kinnunen, Chem. Phys. Lett. 532, 110-115 (2012), https://doi.org/10.1016/j.cplett.2012.02.061.

[6]. G. Gorbenko, V. Trusova, E. Kirilova, G. Kirilov, I. Kalnina, A. Vasilev, et al., Chem. Phys. Lett. 495, 275-279 (2010), https://doi.org/10.1016/j.cplett.2010.07.005.

[7]. O. Ryzhova, K. Vus, V. Trusova, E. Kirilova, G. Kirilov, G. Gorbenko, P. Kinnunen, Methods. Appl. Fluoresc. 4, 034007 (2016), https://doi.org/10.1088/2050-6120/4/3/034007.

[8]. X. Yang, W.-H. Liu, W.-J. Jin, G.-L. Shen, R.-Q. Yu, Spectrochim. Acta. A55, 2719-2727 (1999), https://doi.org/10.1016/S13861425(99)00161-4.

[9]. V. Trusova, E. Kirilova, I. Kalnina, G. Kirilov, O. Zhytniakivska, P. Fedorov, G. Gorbenko, J. Fluoresc. 22, $953-959$ (2011), https://doi.org/10.1007/s10895-011-1035-8.

[10]. O. Zhytniakivska, V. Trusova, G. Gorbenko, E. Kirilova, I. Kalnina, G. Kirilov, et al., J. Fluoresc. 24, $899-907$ (2014), https://doi.org/10.1007/s10895-014-1370-7.

[11]. D. Staneva, E. Vasileva-Tonkova, T.R. Sobahi, R.H. Abdel-Rahman, A.M. Asiri, I. Grabchev. J. Photochem. Photobiol. B: Biology. 143, 44-51 (2015), https://doi.org/10.1016/j.jphotobiol.2014.12.024.

[12]. D. Staneva, E. Vasileva-Tonkova, I. Grabchev. J. Photochem. Photobiol. A: Chemistry. 375, 24-29 (2019), https://doi.org/10.1016/j.jphotochem.2019.02.004.

[13]. O. Zhytniakivska, V. Trusova, G. Gorbenko, E. Kirilova, I. Kalnina, G. Kirilov, et al., J. Luminescsc. 146, $307-313$ (2014), https://doi.org/10.1016/j.jlumin.2013.10.015.

[14]. I. Kalnina, R. Bruvere, T. Zvagule, N. Gabruseva, L. Klimkane, E. Kirilova, et al., J. Fluoresc. 20, 9-17 (2010), https://doi.org/10.1007/s10895-009-0515-6.

[15]. I. Kalnina, L. Klimkane, E. Kirilova, M. Toma, G. Kizane, I. Meirovics, J. Fluoresc., 17, 619-625 (2007), https://doi.org/10.1007/s10895-007-0249-2.

[16]. I. Kalnina, T. Zvagule, R. Bruvere, I. Meirovics, J. Fluoresc., 15, 105-110 (2005), https://doi.org/10.1007/s10895-005-2516-4.

[17]. I. Kalnina, T. Zvagule, N. Gabruseva, et al., J. Fluoresc., 17, 633-638 (2007), https://doi.org/10.1007/s10895-007-0256-3.

[18]. S. Jo, T. Kim, V. G. Iyer, W. Im. J. Comp. Chem. 29, 1859-1865 (2008), https://doi.org/10.1002/jcc.20945.

[19]. .S. Kim, J. Lee, S. Jo, C.L. Brooks, H.S. Lee, W. Im, J. Comp. Chem. 38, 1879-1886 (2017), https://doi.org/10.1002/jcc.24829.

[20]. J. Lee, D.S. Patel, J. Ståhle, S-J. Park, N.R. Kern, S. Kim, et al., J. Chem. Theory Comp. 15, 775-786 (2017), https://doi.org/10.1021/acs.jctc.8b01066.

[21]. T. Darden, D. Yolk, L. Pedersen, J. Chem. Phys. 98, 10089-10092 (1993), https://doi.org/10.1063/1.464397.

[22]. B. Hess, H. Bekker, H.J.C. Berendsen, J.G.E.M. Fraaije, J. Comp. Chem. 18, 1463-1472 (1997), https://doi.org/10.1002/(SICI)1096-987X(199709)18:12<1463::AID-JCC4>3.0.CO;2-H.

[23]. H. Berendsen, J. Postma, W. van Gunsteren, A. DINola, J. Haak, J.Chem. Phys. 81, 3684-3690 (1984), https://doi.org/10.1063/1.448118.

[24]. S. Buchoux, FATSLiM/fatslim: FATSLiM v 0.2.1 (2016), https://doi.org/10.5281/zenodo.158942.

[25]. Yi. Wang, D.E. Schalamadinger, J.D. Kim, J.A. McCammon, Biochim. Biophys. Acta, 1818, 1402-1409 (2012), https://doi.org/10.1016/j.bbamem.2012.02.017.

[26]. H. Jang, B. Ma, T.Woolf, R. Nussinov, Biophys. J., 91, 2848-2859 (2006), https://doi.org/10.1529/biophysj.106.084046.

[27]. V. Trusova, G. Gorbenko, U. Tarabara, K. Vus, O Ryzhova, East Europian Journal of Physics, 4, 54-62 (2017), https://doi.org/10.26565/2312-4334-2017-3-08.

[28]. A. Kyrychenko, T. Dyubko, Biophys. Chem. 136, 23-31 (2008), https://doi.org/10.1021/jp0102567.

[29]. Y.O. Posokhov, A. Kyrychenko, Comput. Biol. Chem. 46, 23-31 (2013), https://doi.org/10.1016/j.compbiolchem.2013.04.005.

[30]. T.J, Yacoub, A.S. Reddy, I. Szleifer, Biophys J. 101, 378-385 (2011), https://doi.org/10.1016/j.bpj.2011.06.015.

[31]. Y.O. Posokhov, A. Kyrychenko, Biophys. Chem. 235, 9-18 (2018), https://doi.org/10.1016/j.bpc.2018.01.005.

[32]. A.M.T.M. do Canto, J.R. Robalo, P.D. Santos, et al., Biochim. Biophys. Acta, 1858, 2647-2661 (2016), https://doi.org/10.1016/j.bbamem.2016.07.013.

[33]. O. Garcia-Beltran, N. Mena, O. Yanez, J. Caballero, V. Vargas, M. Tunes, et al., Eur. J. Med. Chem. 67, 60-63 (2013), https://doi.org/10.1016/j.ejmech.2013.06.022.

[34]. M.W. Baig, M. Pederzoli, P. Jurkiewicz, L. Cwiklik, J. Pittner, Molecules, 23, 1707 (2018), https://doi.org/10.3390/molecules23071707.

[35]. J. Barucha-Kraszewska, S. Kraszewski, P. Jurkiewicz, C. Ramseyer, M. Hof, Biochim. Biophys. Acta, 1798, 1724-1734 (2010), https://doi.org/10.1016/j.bbamem.2010.05.020.

[36]. J. Repakova, P. Capcova, J. Holopainen, I. Vattulainen, J. Phys. Chem. B, 108, 13438-13448 (2004), https://dx.doi.org/10.1021/jp048381g.

[37]. M. Pasenkiewicz-Gierula, T. Rog, K. Kitamura, A. Kusumi, Biophys J. 78, 1376-1389 (2000), https://doi.org/10.1016/S00063495(01)75867-5.

[38]. T. Rog, M. Pasenkiewicz-Gierula, FEBS Letters, 502, 68-71 (2000), https://doi.org/10.1016/S0014-5793(01)02668-0.

[39]. L. Janosi, A.A. Gorfe, J. Chem. Theory Comput. 6, 3267-3273 (2010), https://doi.org/10.1021/ct100381g. 


\section{МОЛЕКУЛЯРНО-ДИНАМІЧНЕ ДОСЛІДЖЕННЯ ВЗАЕМОДІЇ БЕНЗАНТРОНОВОГО ЗОНДУ $З$ МОДЕЛЬНИМИ ЛІПІДНИМИ МЕМБРАНАМИ \\ О. Житняківська}

Кафедра медичної фізики та біомедичних нанотехнологій, Харківський начіональний університет імені В.Н. Каразіна

м. Свободи 4, Харків, 61022, Украӥна

Бензантронові зонди широко відомі як чутливі до змін їх мікрооточення сенсори для дослідження фізико-хімічних властивостей та структурних змін ліпідних мембран. В даній роботі методом молекулярно-динамічного моделювання досліджено локалізацію в ліпідному бішарі та природу взаємодій між бензантроновим флуоресцентним зондом АВМ i модельними мембранами, що складалися із цвіттеріонного ліпіду фосфатидилхоліну (ФХ) і його сумішей з аніонним ліпідом фосфатидилгліцерином (ФГ) і холестерином (Хол). Молекулярно-динамічне дослідження проводили 3 використанням CHARMM36m силового поля в програмному пакеті GROMACS. Продемонстровано, що молекула АВМ, яка спочатку була розташована на відстані $30 \AA \AA$ від центру бішару, проникала в мембрану протягом перших 10 нс моделювання, залишаючись в ліпідному бішарі на протязі решти часу симуляції. Результати молекулярно-динамічного дослідження свідчать про те, що локалізація бензантронового зонду АВМ в ліпідному бішарі в значній мірі залежить від складу мембрани, та варіюється від 0,78 нм в чистому ФХ бішарі до 0,95 нм і 1,5 нм в ліпідних бішарах , що містили ФГ та Хол, відповідно. Виявлено, що при взаємодії АВМ з чистим ФХ бішаром відбувається перехід зонду з зовнішнього моношару ліпідного бішару на внутрішній. Досліджено вплив зонду на структуру ліпідних бішарів. Було виявлено, що розподіл АВМ в ліпідну фазу не має суттєвого впливу на орієнтацію ланцюгів жирних кислот та викликає збільшення дейтерієвого параметру порядку для атомів вуглецю 5-8 в sn- 2 ацильних ланцюгів ФХ ліпідного бішару. Крім того, взаємодія АБМ з модельними ліпідними мембранами супроводжувалась незначним зменшенням площі поверхні на ліпід, що вказує на незначне збільшення щільності упаковки ліпідних молекул у присутності АБМ. Отримані результати створюють основу для більш глибокого розуміння взаємодії бензантронових зондів з мембранами та можуть бути корисні для розробки нових флуоресцентних зондів для мембранних досліджень.

КЛЮЧОВІ СЛОВА: АБМ, бензантроновий зонд, ліпідний біслой, молекулярно-динамічне моделювання

\section{МОЛЕКУЛЯРНО-ДИНАМИЧЕСКОЕ ИССЛЕДОВАНИЕ ВЗАИМОДЕЙСТВИЯ БЕНЗАНТРОНОВОГО ЗОНДА С МОДЕЛЬНЫМИ ЛИПИДНЫМИ МЕМБРАНАМИ \\ О. Житняковская}

Кафедра медицинской физики и биомедицинских нанотехнологий, Харьковский национальный университет имени В.Н. Каразина пл. Свободы 4, Харьков, 61022, Украина

Бензантроновые флуоресцентные красители широко известны как чувствительные к окружающей среде сенсоры для мониторинга физико-химических свойств и структурных изменений липидных мембран. В данной работе методом молекулярно-динамического моделирования исследована локализация зонда в липидном бислое и природа взаимодействия между бензантроновым флуоресцентным зондом АВМ и модельными липидными мембранами, состоящими из цвиттерионного липида фосфатидилхолина $(Ф \mathrm{X})$ и его смесей с анионным липидом фосфатидилглицерином (ФГ) и холестерином (Хол). Моделирование МД проводилось в силовом поле CHARMM36m с использованием пакета GROMACS. Показано, что молекула АВМ, которая была первоначально размещена на расстоянии $30 \AA$ от центра бислоя, встраивалась в мембрану в течение первых 10 нс моделирования, оставаясь в липидном бислое на продолжении остального времени симуляции. Результаты молекулярно-динамического моделирования свидетельствуют о том, что локализация бензантронового зонда АВМ в липидном бислое в значительной степени зависит от состава мембраны, сдвигаясь от 0,78 нм в чистом ФХ бислое до 0,95 нм и 1,5 нм в ФГ- и Хол-содержащих мембранах, соответственно. Обнаружено, что взаимодействие $\mathrm{ABM}$ с чистым ФХ бислоем сопровождалось переходом зонда из внешнего шара липидного бислоя во внутренний. Отдельная серия симуляций MD была направлена на изучение влияния АBM на структуру липидного бислоя. Было обнаружено, что встраивание АБМ в липидные бислои различного состава не оказывает существенного влияния на ориентацию цепей жирных кислот и приводит лишь к небольшому увеличению дейтериевого параметра порядка для атомов углерода 5-8 sn- 2 ацильных цепей ФХ мембран. Кроме того, обнаружено, что взаимодействие АБМ с модельными липидными мембранами вызывает небольшое уменьшение площади поверхности на липид, что указывает на незначительное увеличение плотности упаковки молекул липидов в присутствии АБМ. Полученные результаты создают основу для более глубокого понимания взаимодействия бензантроновых красителей с мембранами и могут быть полезны для разработки новых флуоресцентных зондов для исследования мембран.

КЛЮЧЕВЫЕ СЛОВА: АБМ, бензантроновый зонд, липидный бислой, молекулярно-динамическое моделирование 